\title{
The governance of self-organization: Which governance strategy do policy officials and citizens prefer?
}

\author{
José Nederhand $^{1}$ (D) Erik-Hans Klijn $^{1} \cdot$ Martijn van der Steen ${ }^{1} \cdot$ Mark van Twist $^{1}$ \\ Published online: 18 December 2018 \\ (c) The Author(s) 2018
}

\begin{abstract}
This article compares views of policy officials and members of community-based collectives on the ideal role of government in processes of community self-organization. By using Q methodology, we presented statements on four different governance perspectives: traditional public administration, New Public Management, network governance, and selfgovernance. Perceptions differ about how government should respond to the trend of community self-organization and, in particular, about the primacy of the relationship. Whereas some public servants and collectives favor hands-off involvement of policy officials, others show a preference for a more direct and interactive relation between government and community-based collectives. In general, neither of the two groups have much appreciation for policy instruments based on performance indicators, connected to the New Public Management perspective or strong involvement of politicians, connected the traditional public administration perspective. This article contributes to the discussion of how practitioners see and combine governance perspectives and serve to enable dialogs between practitioners.
\end{abstract}

Keywords Governance modes · Policy $\cdot$ Q methodology $\cdot$ Community-based collectives

\section{Introduction}

Civic engagement around public issues is changing, leading to new forms of community organizing, also referred to as 'self-organization' in the literature (Eriksson 2012; Edelenbos et al. 2018). As a correction mechanism to the perceived failure of centralized and impersonal service provision by government and private parties, communities develop small-scale community-based services in which people have a say (Gofen 2015; Healey 2015; De Moor 2015). As part of a larger cultural and political development, many diverse collectives, such as community enterprises and cooperatives, have emerged to complement or even substitute professional services (see, for example, Peredo and Chrisman 2006; Kleinhans 2017). These self-organizations are new in the sense that they are an attempt to

José Nederhand

nederhand@essb.eur.nl

1 Erasmus School of Social and Behavioral Sciences, Erasmus University Rotterdam, Burgemeester Oudlaan 50, PO Box 1738, 3000 DR Rotterdam, The Netherlands 
break away from community organizing as either participating in government actions, or opposed to government initiatives, but as unrelated to government ${ }^{1}$. In this article, we use the term community-based collectives to refer to groups of citizens that initiate, own, and exploit specific collective community-based services. ${ }^{2}$ As community-based collectives establish themselves as independent players in an already crowded and institutionalized public field, entering into some kind of relationship with government is almost a prerequisite (Edelenbos et al. 2009; Bekkers et al. 2014).

\section{This article: assessing governance preferences of citizens and policy officials}

Although we see a growing number of these community-based collectives and, accordingly, see a growing attention given in the literature to how they organize themselves (Nederhand et al. 2016; Edelenbos et al. 2018), there is very little research on what form of governance is actually preferred by policy officials and collectives. As a first step in researching the (causal) question of the effects of such relationship, this study systematically examines the perceptions on relevant governance orientations among both local policy officials and key members of collectives. The central question of this article is: How do policy officials and key members of community-based collectives perceive the (ideal) governance relationship between government and collectives? Our main contribution is twofold. First, this article contributes to the theoretical debate about what governance modes various actors prefer, but also how various governance perspectives, and accompanying policy mechanisms, are combined (See Levi-Faur 2012; Lægreid 2016). In this research, we identify four governance modes, which involve different preferences for policy instruments, that are expected to attain the general aim of government (Salamon 1981; Considine 2001; Howlett 2009). Promotion of dichotomous sets of governance strategies like 'market versus state' or 'hierarchical versus collaborative' led to blunt thinking about instruments and their modalities which is not helpful for furthering understanding of policy design (Howlett 2014). That is to say, administrative practice usually involves the use of multiple tools in policy instrument mixes. However, the nature of these mixes and how behavioral aspects of policymakers lead them to favor one design over another remains understudied (Bressers and O'Toole 2005; Eliadis et al. 2005; Howlett 2018). Our contribution is a modest, but essential first step in developing a more ambitious research agenda on how mixes of normative expectations affect results of community-based collectives. Second, this article provides a firm basis for facilitating dialogs between practitioners about these views by providing a theoretically grounded exploration on diverging views of governance steering between these two groups. A mismatch in normative expectations and attitudes on how the relationship between policy officials and community-based collectives should be organized and governed might have important consequences for the chances of success of collectives (for

\footnotetext{
1 Of course, from a historical point of view, these community-based collectives are anything but new since early examples of self-organization historically preceded the development of the state-controlled services of the twentieth century, and have been present ever since (De Moor 2015; Denters 2016). Contrary to the more historical instances of community-based collectives, these 'new' collectives establish themselves as independent players in an already crowded and institutionalized public field.

2 We do not refer to entire communities that are self-organized, but specific organizational entities, 'collectives' organized around a specific function-which also implies that these community-based collectives operate within the bounds of regular society, with all the normal rules and regulation.
} 
example Edelenbos et al. 2009; Nederhand et al. 2016). Hence, the issues of steering and intervention are key attributes of effective policy making (Hajer 2003).

To gain insight into the differing perspectives on governance relationships, we use Q methodology (Brown 1980), a methodology especially suitable for identifying and systematically and scientifically mapping underlying inter-subjectivity on a topic. We first distinguish and discuss four theoretical perspectives on governance ("Perspectives on governance" section). We then explain the research method (Q methodology), how we used it, and how we constructed the statements for the sort process, for which we used the literature on governance perspectives ("Research design: Q sort statements and respondents' selection" section). Next, we analyze the distinction in governance perspectives between the two groups of respondents ("Results" section). In the final section, we address important conclusions and limitations and consider avenues for future research.

\section{Perspectives on governance}

There is a massive literature on the relationship between government and society and on governance as the way policy is formed and implemented to influence that relationship and achieve public goals. Within this literature, it is possible to distinguish coherent clusters that share a specific focus on certain elements or values of governance; these elements are not coherent theories, but rather joint perspectives on what is important in governance (e.g., Bourgon 2011). Such perspectives can be useful for studying the exchange relationship of government and community-based collectives. For the purpose of this study, we have discerned four perspectives on governance that reflect clusters in the literature and have proven to be recognizable and relevant in the view of practitioners. We discern the following four perspectives: traditional public administration, New Public Management, network governance, and self-governance ${ }^{3}$. We will discuss each perspective briefly and present the consequences of each perspective for the relation between government and community-based collectives. We do not strive toward a definitive clustering of the governance literature, but for a lens that can be used to study the perceptions of the mutual interaction between policy officials and active citizens. We also acknowledge that the fourth perspective (self-governance) is the least well known and least well developed. The perspectives can help us to generate statements for the empirical analysis of the perceptions of respondents on governance. At the end of this section, we compare the four governance perspectives and highlight similarities and differences.

\footnotetext{
3 We want to emphasize that we present governance perspectives here, so more or less coherent ideas on how to govern state-society relations and to form and implement policy. That is not exactly the same as coordination mechanism as is sometimes presented in more economic literature (see Ostrom 2010) or organizational literature (Powel 1990) like market, hierarchies and networks although the two are related. But in governance perspectives much more other aspects are emphasized than in the literature about coordination mechanism [for instance, in the governance network perspective, as we distinguish it, much emphasizes is laid on network management as governance strategy, while this does not receive much attention in the literature on networks as coordination mechanism (see Powel 1990)].
} 


\section{Traditional public administration: safeguarding public values}

The first theoretical perspective examined is that of traditional public administration (TPA). This perspective focuses on governance as ensuring legal(istic) values, achieving political goals, and safeguarding public values, especially equal treatment, legality, and democracy (Wilson 1989). Governmental organizations are characterized as impersonal rational systems that prescribe neutral behavior for policy officials (Weber 1978). Political goals of officeholders are favored, and so political decisions guide what policy officials should do. Moreover, this perspective emphasizes the rule of law and legalistic values. The presence of impersonal and stable rules shields citizens from arbitrariness, power abuse, and personal whims (Bartels 2013). With regard to collectives, this implies that the interaction should take place along the lines of clear regulations. The explicit standardization of functions, processes, and rules makes interaction with the bureaucratic organization perfectly predictable (Dror 1968). Hence, public values, such as impartiality and impersonality, which guarantee that values of equality, transparency and democracy are not violated, are key. From a TPA perspective, safeguarding these public values is especially important now that collectives are becoming increasingly prominent in public service provision. Therefore, to compensate for failures within civil society, government should use policy instruments that regularize collectives that provide services to citizens to ensure that they meet those public values of equality and democracy.

\section{New Public Management: governing through performance indicators}

The second perspective is that of New Public Management (NPM). It is difficult to provide a definitive image of NPM (Pollitt et al. 2007; see Hood 1991; Lane 2000). However, the main features of NPM focus on improving the efficiency and effectiveness of public service delivery through the use of policy instruments that focus on the management of processes and systems. In the NPM view, governments decide what they want, specify outputs, and then decide which organizations - public but autonomous, nonprofit, or private-can best deliver the service (Osborne and Gaebler 1992). Moreover, the use of business instruments (strategic and performance management techniques and performance indicators) are crucial to any conceptualization of NPM (See Hood 1991). For this idea to work, two very important conditions have to be met: goal specification and monitoring capability. Thus, public actors have to be able to define goals and translate these into performance indicators and actually be able to monitor the implementation of the actors' activities. In this perspective, governments thus occupy a superordinate position in relation to collectives that provide services (e.g., principal-agent relation). Once performance indicators have been set, policy officials can take a more hands-off approach to their monitoring role.

\section{Network governance: managing performance through joint interaction}

The third perspective is that of network governance. Here, government relates to collectives in a more horizontal way, resulting in more intense interactions. Governing takes place through the usage of procedural policy tools (Howlett 2000). Procedural tools, like process design rules, or arranging interactions, can be seen as techniques of network management (Agranoff and McGuire 2001; Klijn and Koppenjan 2016). They are aimed at altering and improving policy interaction, but they do so indirectly by structuring interactions without determining their outcome (Howlett 2018). The governance perspective emphasizes 
the importance of inter-organizational coordination and quality of decision making (Klijn and Koppenjan 2016). In this perspective, public goals and policies are defined and implemented through a process of interaction and negotiation; policy and service delivery are achieved in networks of mutually dependent actors. Managerial efforts of policy officials focus on activating actors, organizing joint-research meetings (joint fact finding), and composing a set of mutually agreed upon rules of behavior. Whereas the relationship between government and collectives under NPM is more strongly contractual and performance based, in network governance it is a more interdependent horizontal relationship, with emphasis on joint action and facilitating cooperation to deliver societal outcomes.

\section{Self-governance: fostering autonomy of community-based collectives}

Recently, the perspective of self-governance has been re-emerging (Bourgon 2011; Sørensen and Torfing 2007). Naturally, the idea that (small) groups of people can organize collective goods without market mechanism or hierarchy has been emphasized by others, not the least Elinor Ostrom. Sometimes, this is presented as 'clubs' (see Ostrom 2010): groups of individuals that create private associations to provide themselves with non-rival but small-scale goods and services, but also exclude non-members.

As a governance perspective, thus how it is used in this article, the idea of self-governance has a long history (for instance, in the nineteenth century, when various collectives were established to solve social problems). The key point of this perspective is that the dynamics that produce public value start within society and, as such, government relates to that (De Moor 2015). For example, government can relate to these initiatives of society by letting go, by blocking, by facilitating, or by attempting to 'organize' more selforganization (Nederhand et al. 2016; van der Steen et al. 2016). Thus, governments tend to follow and improve self-organization of citizen and society initiatives rather than initiate and organize them. Self-governance is not equivalent to a laissez-faire approach to government (see also Rhodes 1997), nor does it imply that self-organization is disconnected from government action. Almost all self-organizing activities take place within the bounds of government jurisdiction and in regulated spaces and involve interests of other stakeholders-either in or outside the self-organized community. The essence of this governance perspective is that because societal actors take action themselves, government actors need to relate to these often-uninvited actions (see Sørensen and Torfing 2007). The policy instruments appropriate for the self-governance perspective would thus be more restrained. They would include things like removing barriers for collectives to function, supporting them by providing fast access to public decision making, and maybe encouraging collectives by small subsidies. But essentially governments would stay away from steering strongly on the content (which is been done in the network perspective). Although the selfgovernance mode of governance contains elements of the network governance perspective in the sense that both emphasize a more horizontal type of relationship between the public and societal sphere, we observe several significant differences which makes it logical to identify them as separate perspectives. In the network governance perspective, the government does have a very active role in linking, collaborating, and co-producing services with the collective by intense network management strategies. In the self-governance perspective, goals of collectives are emphasized more and government is not very active in managing the relation and the output of the service. Thus, in a self-governance perspective, 
governments are not really co-producing services with collectives but are at larger distance only facilitating and reducing obstacles.

\section{The four perspectives compared}

The governance relationship between government and community-based collectives can therefore be perceived in very distinct ways. When the theoretical perspectives are applied to different aspects of this relationship, each mode has a different view (See Table 1). Based on the well-established practice of NPM and network governance, in particular, we would expect policy officials to embrace these two perspectives. For collectives, on the other hand, we expect a preference for the self-governance perspective.

\section{Research design: $Q$ sort statements and respondents' selection}

Q methodology is increasingly applied by public administration scholars in the systematic study of perceptions (Durose et al. 2015). In brief, Q methodology presents a series of statements representative of the debate on an issue to the respondents, who are asked to sort the statements into a distribution of preference (a Q sort). From this distribution, statistically significant factors are derived and interpreted (Watts and Stenner 2012). By using Q methodology, it is possible to develop a set of statements based on the four perspectives identified in Sect. 2 and administer these statements in random order to policy officials and community-based collectives to explore whether and how these perspectives operate in practice. Hence, respondents are not presented the perspectives, but only the individual statements derived from them. By measuring perceptions rather than actual behavior, the Q sort concerns the studying of subjectivity. The usage of a statistical tool in combination with a well-developed stepwise approach makes the method explicit and replicable (Watts and Stenner 2012; McKeown and Thomas 2013). We will now explain the threestep approach that we followed.

Q methodology first requires researchers to comprehensively capture the diversity of the debate. There are several ways to establishing the breath of the debate around a particular issue (see Jeffares and Skelcher 2011; Watts and Stenner 2012), by using interviews, focus groups, policy and/or media discourses, and academic discourses. In this article, we take the academic discourse as a starting point (see Durning and Osuna 1994; Klijn et al. 2016). This allows researchers to relate the profiles that result from the empirical analysis more strongly to existing theoretical debates. We, therefore, started to develop sample statements by extracting a long list of statements from our reading of the literature around the four perspectives outlined in Sect. 2. By systematically sorting the statements in a $3 \times 2$ grid (see Table 2), we reduced the number of statements while simultaneously safeguarding the diversity of the debate. Our approach follows the statement-sampling method developed by Dryzek and Berejikian (1993). Across the horizontal axis, the grid considers three types of statements that are relevant for examining the relationship between government and collectives: relationships between entities, degrees of agency and governance profession. In addition, across the vertical axis, the grid considers two types of statements: definitions and prescriptions following, for instance, those of Jeffares and Skelcher (2011) and Klijn et al. (2016). To ensure a balanced sample, we retained four statements in each cell. Each 


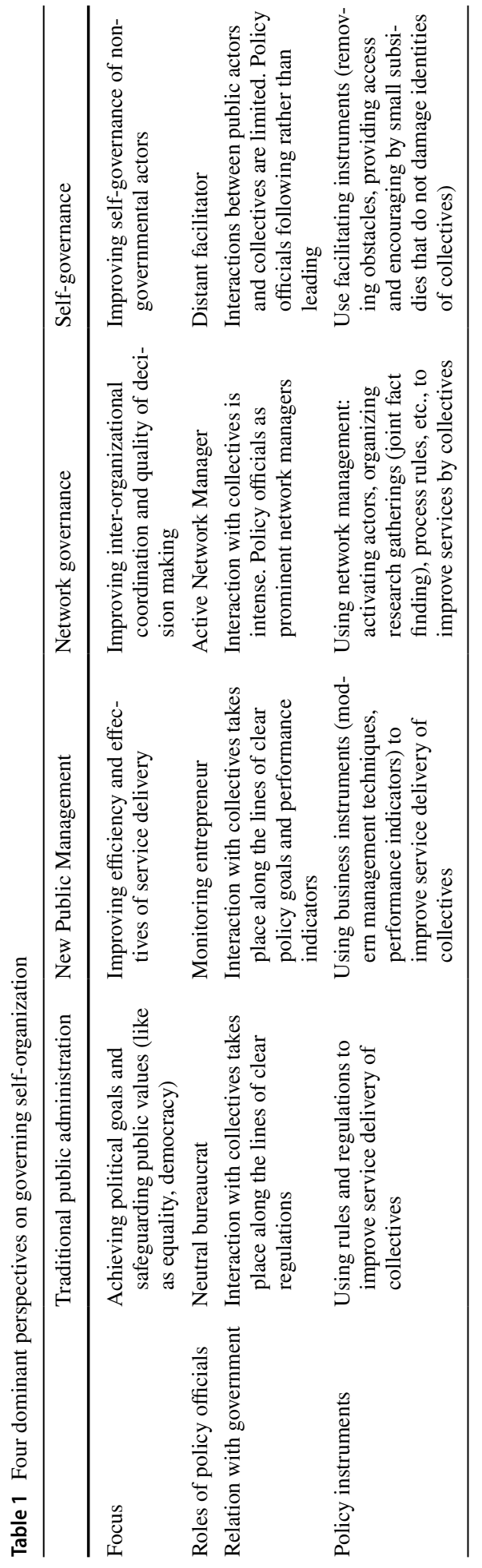




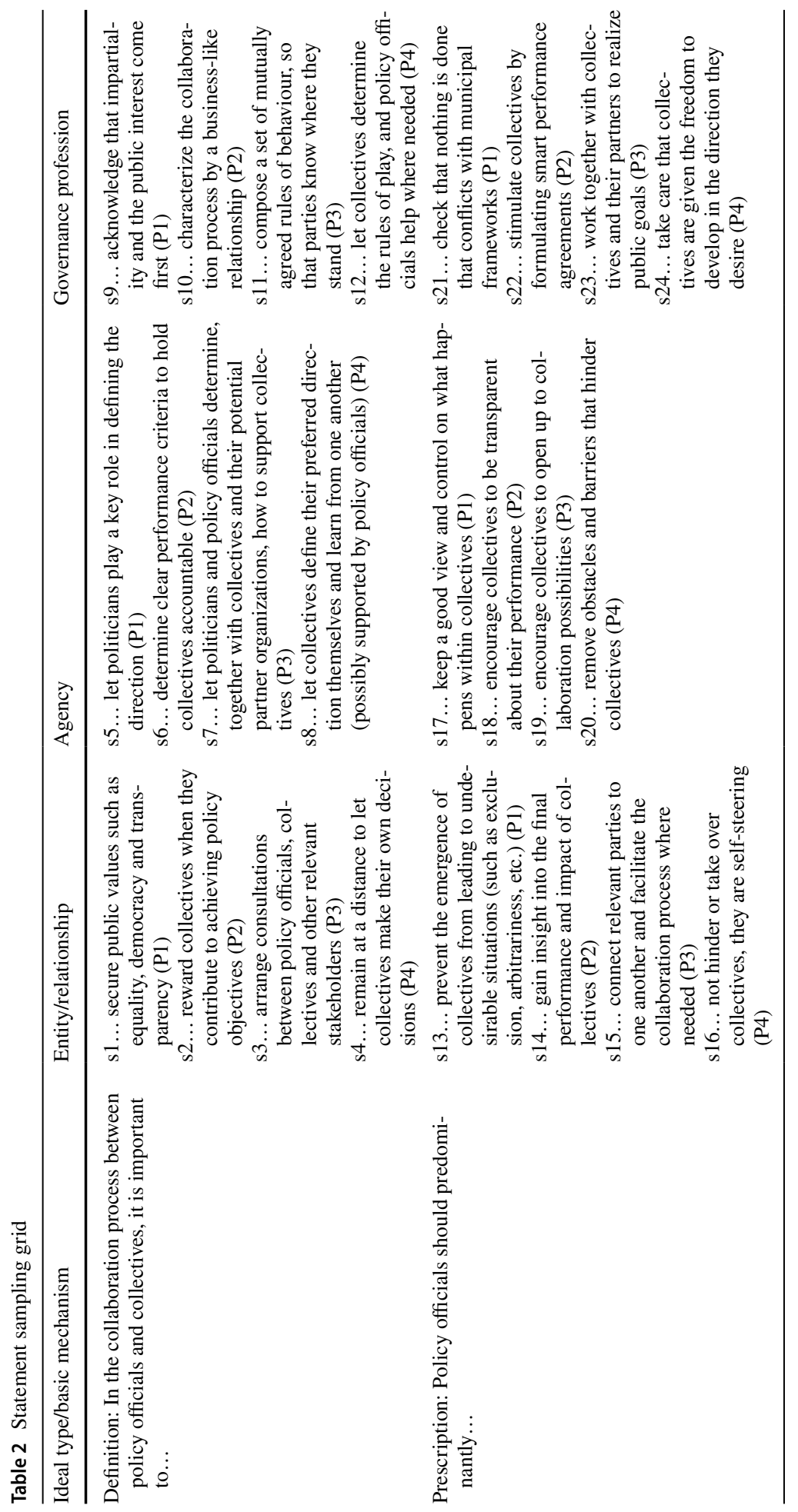


statement is inspired by one of the four perspectives, resulting in a total of 24 statements (See Table 2 below).

To ensure the compatibility of the statements with the practitioners' experiences, we conducted a pilot study. Before activating the study online, the preliminary Q-set was tested 'offline' in a face-to-face setting. We instructed two participants from the side of collectives (one initiator and one expert working for an umbrella organization specializing in community-based collectives) and two policy officials to sort the statements and to list the statements that they failed to understand, found similar in meaning, or considered irrelevant. We also asked whether they had additional remarks about missing crucial dimensions. Their feedback resulted in several adjustments and refinements of the Q-set.

The second step is to present the study to participants: in this case, policy officials and collectives. Most Q studies find samples of between 25 and 40 respondents sufficient to establish the number of shared subjective viewpoints operant around a topic (Brown 1980; Watts and Stenner 2012). Our P set is composed of 40 policy officials and 40 collectives. The participants are working in the field of care and welfare in the Netherlands. We find this domain specifically important to study as this policy area is traditionally characterized by a strong government presence. Given the demographic of our P set, we decided to administer our study online using an application called POETQ ${ }^{4}$. We asked the participants in a corresponding email to let us know when they had difficulties with the Q sorting procedure so that we could offer additional instructions.

We emailed a link to the online Q sort to 80 policy officials working in Dutch local governments. The policy officials whom we approached are involved in policymaking functions in departments of medium-to-large-sized municipalities that focus upon designing care and welfare policies. We strived to select policy officials who have direct contact with collectives. Around 35\% of the participants consisted of professional contacts from our network in this sector, while the other $65 \%$ were selected by top officials, who send out the invitation to the welfare policy department in their organization. A total of 40 people completed the Q sort (50\% response rate). Despite our efforts to only select officials who are experienced in working with community-based collectives, a small minority of policy officials indicated that they did not have much contact with collectives. As the differences with their colleagues who had direct contact were small, we chose to keep these policy officials included in our analysis. Furthermore, we emailed a link to the online Q sort to 95 initiators of care and welfare collectives in the Netherlands. We only selected collectives that are community-based organizational entities initiated, owned, and controlled by citizens and are organized around a specific welfare/care function. They are thus distinct from government (and cannot be attributed as co-productions). With regard to the collectives, we also selected participants in two different ways to counteract a potential bias. We made use of two online databases: MAEX and Vilans. In the case of the MAEX database, collectives need to register themselves. Via the database that is linked to a website (https://www. maex.nl/initiatieven/), collectives make their societal value transparent and can get better connected to funds and possible partners or volunteers. This implies a certain amount of digital skills on the side of the collectives. The Vilas database consists of 170 care and welfare collectives. These collectives were actively spotted and included by the organization Vilans itself. For the collectives, this implies that they need to be visible to the professionals of Vilans to be added to the database. In conclusion, a potential bias exists in favor

\footnotetext{
${ }^{4}$ https://stephenjeffares.wordpress.com/poetq/.
} 
of those collectives with good digital and networking skills. In selecting the collectives, we also took the phase of the initiative into account as this can influence perceptions regarding governance issues. We only approached collectives that were well established and had thus transited the initiating phase. A total of 40 people completed the Q sort ( $42 \%$ response rate).

The third step concerns the process of Q sorting. Our participants sorted the 24 statements into seven piles representing the seven degrees of agreement, ranging from 'most agree' (+3) to 'least agree' (-3) (See “Appendix 1"). Subsequently, the respondents had to choose between statements, as they were restricted in how many statements they could place in each pile. Respondents are not presented with the perspectives but only with the individual statements (in random order). With regard to the reliability of findings, there is a double-check in the POETQ program, namely (1) by showing the pyramid/sort and asking whether the participant confirms the order and (2) by explicitly showing the statements the participant agreed and disagreed with most and asking for clarification and reflection on the reasons why they did so. By these means, the respondents were given the opportunity to reflect on their choice of statements with which they agreed and disagreed with the strongest. Almost all participants used these options for reflection: 40/40 policy officials and 37/40 collectives. This double-check method enhances the reliability of our findings since respondents have to check and confirm their choices. For a more elaborate explanation of the POETQ procedure, see, for instance, Watts and Stenner (2012).

\section{Analysis}

We used the software package PQ method to perform two seperate factor analysis (Schmolck and Atkinson 2013). Conducting a centroid factor analysis, we extracted four factors: two for policy officials and two for collectives. These four factors all satisfy the standard conditions explicated by Watts and Stenner (2012), namely that their eigenvalues exceed one and that two or more people load significantly on each factor (See Appendix 2). Each profile is informed by the loading of between 9 and $21 \mathrm{Q}$ sorts. The degree to which participants are associated with each factor is indicated by the magnitude of factor loadings. The significance of a loading is calculated on the basis of the number of statements in the Q sample (Brown 1980). With 24 statements, the significant loading on the sort is calculated to be 0.53 at $p<.01$. To maximize the number of unique factor loadings, participants with a loading of 0.53 and above were flagged for a varimax rotation (See Appendix 3). Of the 80 participants, 60 had a loading on one of the four factors. This is in line with what can be expected in a Q study (Jeffares and Skelcher 2011).

\section{Results}

From our data, we constructed four factor profiles: two for policy officials and two for collectives. As our Q study is theoretically driven, we interpret the factors in relation to the four governance perspectives set out in Sect. 2 (See also Appendix 3). 


\section{Facilitators (21 policy officials significantly associated)}

The first profile identifies policy officials as Facilitators. For these policy officials, the role of government is in the background: they strongly support the self-governance perspective. They believe that non-interference is key to maintain collectives' feeling of ownership. This profile is reflected by the characterizing statement 'collectives define their preferred direction themselves and learn from one another (possibly supported by policy officials)' (s8). To facilitate this process of learning, Facilitators stress the connective role of policy officials (s15), thereby embracing some aspects of the network governance perspective. Although Facilitators broadly support the idea of self-governance and not controlling or hindering collectives (s16), they give less priority to the idea of policy officials actively removing obstacles and barriers that hinder collectives (s20) and explicitly taking care that collectives are given the freedom to develop in the direction they desire (s24). The same goes for the network governance statements regarding actively encouraging collectives to open up to collaboration possibilities (s19) and playing a role in composing a set of behavioral rules to let parties know where they stand (s11). Facilitators stress that policy officials should remain at a distance to allow collectives to make their own decisions and determine the rules of play (s4, s12). Consequently, they strongly disagree with the view, as stressed by the NPM perspective, that governments should relate to community-based collectives in a traditional or a business-like manner. Participant 25 explained: 'Then you take out the energy.' Facilitators believe that it is not their job to keep control on what happens within collectives (s17) by, for example, formulating smart performance agreements to hold collectives accountable (s22, s6).

\section{Networking Servants (9 policy officials significantly associated)}

The second profile identifies policy officials as Networking Servants. Networking Servants feel that their main task is to secure such public values as equality, democracy, and transparency in the collaboration process with collectives, as stressed by the TPA perspective. Participant 21 explains: 'It is important to always keep these three values in mind in order to remain trusted by residents and authorities. People expect this from us. If we let these values go, we become unreliable as a government.' On the one hand, Networking Servants agree upon safeguarding public values (s1) and preventing the emergence of collectives from leading to undesirable solutions, such as exclusion and arbitrariness (s13) - statements that resemble the TPA perspective-they strongly disagree with statements from the same perspective that policy officials should act upon this in a top-down manner, with politicians playing a key role in defining the course of events (s17, s5, s21). As such, the Networking Servants' statement preferences reveal two dimensions within the theoretical perspective of TPA: a public values dimension and a top-down governance dimension.

Networking Servants furthermore support statements that come from the network governance perspective about involving other relevant parties in the network around collectives (s3, s15). Or as participant 15 explains: 'As a municipality, you have a reasonably good overview of what is happening in the city and who are active. By encouraging cooperation and bringing the right people into contact with one another, you strengthen initiatives.'

Overall, the orientation of Networking Servants leans more toward the idea of safeguarding public values (TPA) and networking (network governance) than toward facilitating the direction that collectives have chosen (see Facilitators). They, for instance, give 
less priority to self-governance statements such as keeping at an appropriate distance (s4) and not taking over collectives (s16), than the other three profiles. They thus find an active stance more appropriate than their Facilitating colleagues. They share, however, the strong opposition to NPM control and performance criteria (s6). According to Networking Servants, this attitude of government harms (and possibly destroys) collectives' self-organizing capacity.

\section{Independents (16 collectives significantly associated)}

We labeled the first profile of the collectives as Independents. Independents emphasize that policy officials predominantly should take care that collectives are given the freedom to develop in the direction they desire (s24). In their perception, this strongly contrasts with top-down and managerial government involvement. As collectives are dependent upon passion and energy, it is crucial to give them the freedom to set their own rules and steps (s8, s12). They strongly identify with the self-governance perspective, and in line with this, Independents show a clear dislike of political interference, as stressed by the TPA perspective (s5). Respondent 35 explains: 'Political interference can lead to demoralization; by involving the alderman, the process gets drawn into the political arena and this often results in a very laborious process.' Other respondents stress the need for collectives to remain free of political opinions to maintain openness. Independents are further characterized by a strong dislike of most NPM statements, such as their idea of a business-like relationship between collectives and local governments (s22, s6, s10). They feel that the achievement-oriented society is preposterous. Instead, respondents indicate that collectives are often characterized by a focus on outcomes that are difficult to measure. Respondent 26 explains: 'Taking the work that we do into account, the words business and performance are two extremes that don't match. Performance and results are too often crucial in society, unfortunately. What we try to do is to break free and provide people with a sense of selfesteem, utility and welfare. These values are difficult to measure.'

In combining statements from the network governance and the self-governance perspectives, the Independents correspond highly with the policy officials group, the Facilitators. Like the Facilitators, Independents take the view that the role of government should be to connect relevant parties and facilitate the process if needed (s15). Both groups also particularly dislike statements from the TPA and NPM perspectives. All in all, Independents want to be left alone as much as possible.

\section{Entrepreneurs (13 collectives significantly associated)}

We labeled the second profile of the collectives as Entrepreneurs. Entrepreneurs acknowledge the potential of an active and diverse involvement of policy officials, as long as collectives can define their preferred direction themselves (s8). This profile is characterized by the statement (from the NPM perspective) that it is important to reward collectives when they contribute to achieving policy objectives (s2). Distinguishing between initiatives that are performing well and badly can help to further improve the quality of services. As exemplar, key participant 3 explains: 'It happens too often that initiatives that are already performing well are "taken for granted", whereas huge amounts of time and money are spent on new initiatives or badly performing ones.' This also has advantages for governments themselves. Key participants indicate that collectives that are performing well save 
the government money by eliminating and preventing certain problems. This second statement is the only statement from this perspective that is highly supported. For the rest, the NPM statements, in general, are rejected or prioritized less by both policy officials and collectives. Indeed, Entrepreneurs emphasize that they are not an executive agency of government policies.

Entrepreneurs endorse the statement from the self-governance perspective that policy officials should remove obstacles and barriers that hinder collectives (s20), as well as the TPA statement on securing values such as equality, democracy and transparency (s1). They believe that policy officials should be unbiased in collaborating with collectives. It should be about more than who you know and who has a good marketing campaign; rather, it should be about genuine impact and content. This profile highlights again the two dimensions within the traditional perspective (the top-down dimension and the securing values and equity dimension). Entrepreneurs do not like traditional top-down TPA statements, such as checking municipal frameworks (s21), political involvement (s5), and keeping control of collectives (s17). Respondent 24 explains: 'A collective often arises from a sense of dissatisfaction with the current situation. Therefore, it is not desirable that the "current power" acts as judge or jury' (R24). Moreover, Entrepreneurs disagree with the NPM statement on smart performance agreements for collectives (s22). They think that it is not only impossible to measure performance such as social cohesion, well-being, and prevention, but also that it is inappropriate.

Entrepreneurs combine statements from the Traditional, NPM (but only one!) and selfgovernance perspective. In contrast to other profiles, Entrepreneurs find network governance less important in their relationship with policy officials. Being rather confident and active, they do not need government assistance for building and maintaining networks. Namely, maintaining and exploring contacts and networks is one of the defining characteristics of Entrepreneurs.

Table 3 provides an overview of the main characteristics of the four profiles and their connection to the theoretical perspectives.

\section{Conclusion}

Our purpose was to explore the views of policy officials and community-based collectives on governance and examine the ways in which they differ. This exploration is very relevant in the light of the widespread political discourses advocating that communities care of their own local problems and public services, as well as the growth in the number of community-based collectives (see Nederhand and Van Meerkerk 2017; Edelenbos and Van Meerkerk 2016). The question then is how we should respond to this trend; that is, which form of governance is appropriate for-and desired by - the actors involved? To explore this question, we used Q methodology in which we presented respondents with constructed statements on governance based on four governance perspectives: traditional public administration, New Public Management, network governance, and self-governance.

Our study shows that there are roughly two types of governance profiles. The first type perceives the 'ideal' governance relationship as one of 'pure' and somewhat radical selfgovernance. According to this profile, policy officials should not have direct involvement in collectives and keep their distance; the role of government should be to create favorable conditions for collectives. This type of governance is advocated by Facilitators and 


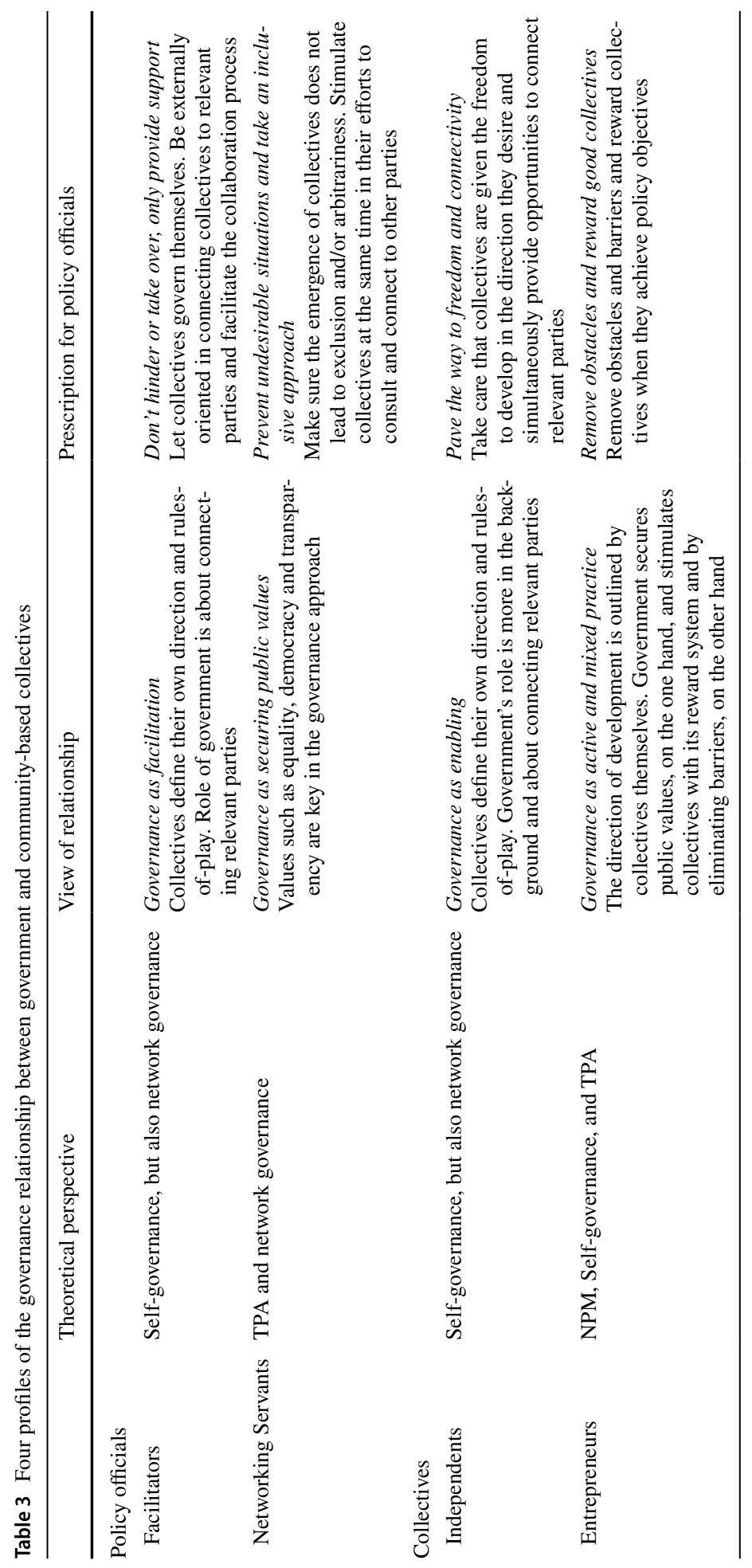


Independents, and we have found this to be a prevalent profile among both policy officials and citizens.

The second type aims for the co-creation of public value and pursues a more direct and interactive relationship between government and community-based collectives. This type sees an important role for community-based collectives within the broader bounds of government policy. It is the role of government to ensure that the self-organizations remain aligned to a broader public interest; therefore, a more hands-on collaboration is preferred here. Government is seen as a partner or platform to help realize the societal ambitions of collectives. Although Entrepreneurs and Networking Servants advocate this type of governance, their precise focus differs. Entrepreneurs believe that their impact on the creation of public values may and, in fact, should be rewarded, whereas Networking Servants see their involvement more in connecting and taking a collaborative approach. Table 3 shows the main characteristics of these profiles.

\section{Limitations of the study}

The study does have several limitations. We derived the q sort statements from literature on governance. This has clear advantages and strengths (like the possibility to connect the resulting factors to the source of the statements, the governance perspectives), but it also has limitations. By using theoretical perspectives as our starting point, we run the risk of missing additional dimensions of the perceptions of our respondents on the issue. To partly obviate this effect and to ensure the compatibility of the statements with practitioners' experience, we conducted a pilot study. Another limitation has to do with the study of perceptions. Although the advantage of applying Q methodology is that it gains insight into practitioners' perceptions, it does not necessarily provide knowledge about how governance actually takes place in practice. It would, therefore, be good to follow up with comparative case studies, in which the different governance perspectives and their applications can be studied more in-depth and also in relation to different settings. Another limitation has to do with the context. This study was conducted among practitioners working on welfare policies and in collectives with a focus on welfare. Follow-up research could compare the governance perceptions in this 'soft' sector to a 'harder' sector, such as the energy sector, where talking about performance measurement may be more natural.

\section{Reflections}

Despites these limitations, we think we have highlighted an interesting and understudied topic in the governance and policy design literature. What becomes clear is that perceptions of both policy officials and community-based collectives differ about how government should respond to this new trend of self-organization, and in particular, about the primacy of the relationship. Whereas Facilitators and Independents favor the relatively light governance perspective of self-governance, with community-based collectives finding their own way, Networking Servants and Entrepreneurs show a preference for a closer relationship in which ideas and policy instruments of all governance modes are mixed. While this research highlights interesting differences in the governance approach that policy officials and collectives prefer the most, this research simultaneously shows that when it comes to the governance approach that is preferred the least, the profiles show some striking similarities. That is all profiles strongly reject the applicability of performance measurement and strong political involvement. It is clear that despite the 
more or less 'distant' way of governing the managerial idea of performance criteria does not resonate at all with both initiators of community-based collectives and with the policy officials. This should probably encourage thinking about policy instrument mixes to arrange the relation between governments and community-based collectives. Mixes that combine the management of objectives with mutual learning processes rather than the more 'associations of punishment' that are connected to the NPM toolkit (see Noordegraaf and Abma 2003; Stoker 2006). When we are rethinking policy instrument mixes we then should also pay attention to perceptions of most respondents in relation to the traditional public administration perspective. Although participants seem to strongly support the underlying (public) values and principles such as preventing exclusion of groups, they are much more critical about the form in which these are sometimes pursued: statements regarding the dominant role of politicians and top-down steering were rejected. Collectives, for instance, feared the laborious process when something 'becomes political.' This resonates with the observation of some authors that strong political interference regarding content seems to be difficult to combine with new governance forms (see, for instance, Klijn and Skelcher 2007). The rejection of political interference could point toward another role for politicians that matches the emphasis placed by respondents on the more traditional guarantee of fundamental democratic values (equal access, equal treatment, and so forth) rather than managerial interference. Thus, politicians would be more concerned with achieving a level playing field, ensuring that self-organizations do not lead to undesired side-effects and exclusion.

By unraveling governance preferences, this research provides a first step to inform and improve the process of policy design in contemporary states (Howlett 2009, 2018). This research suggests that the governance of community-based collectives calls for a design perspective that mixes the instruments and values of the more facilitating selfgovernance perspective with elements of the more traditional, managerial, and network perspectives.

Open Access This article is distributed under the terms of the Creative Commons Attribution 4.0 International License (http://creativecommons.org/licenses/by/4.0/), which permits unrestricted use, distribution, and reproduction in any medium, provided you give appropriate credit to the original author(s) and the source, provide a link to the Creative Commons license, and indicate if changes were made.

\section{Appendix 1: Shape of the response grid}

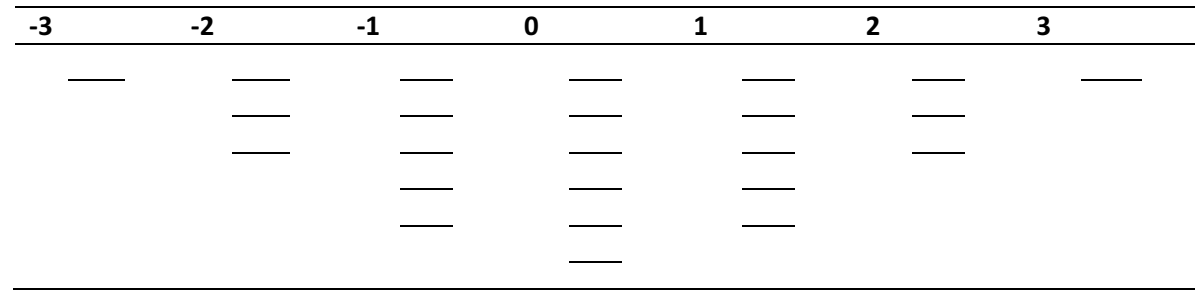


Appendix 2: Factor loadings for $Q$ sorts ( 40 policy officials and 40 collectives)

\begin{tabular}{|c|c|c|c|c|}
\hline & \multicolumn{2}{|c|}{ Policy officials } & \multicolumn{2}{|l|}{ Collectives } \\
\hline & Facilitators & Networking Servants & Independents & Entrepreneurs \\
\hline 1 & -0.0300 & 0.4772 & 0.6148 & 0.6518 \\
\hline 2 & $0.7244 X$ & 0.1059 & 0.1394 & $0.5459 X$ \\
\hline 3 & $0.8930 \mathrm{X}$ & 0.0513 & 0.0367 & $0.8848 \mathrm{X}$ \\
\hline 4 & 0.5036 & 0.2795 & 0.1684 & $0.5650 \mathrm{X}$ \\
\hline 5 & $0.7195 X$ & 0.3525 & 0.3121 & $0.5991 X$ \\
\hline 6 & 0.3742 & $0.5321 X$ & 0.7499X & 0.3258 \\
\hline 7 & 0.4031 & $0.5871 X$ & 0.1958 & $0.6416 \mathrm{X}$ \\
\hline 8 & 0.2258 & 0.4359 & 0.0310 & $0.7892 X$ \\
\hline 9 & $0.6946 \mathrm{X}$ & 0.3451 & 0.3485 & 0.1913 \\
\hline 10 & $0.7625 X$ & 0.1799 & 0.3917 & $0.7485 X$ \\
\hline 11 & $0.5642 \mathrm{X}$ & 0.5161 & 0.2630 & $0.6046 \mathrm{X}$ \\
\hline 12 & $0.7371 \mathrm{X}$ & 0.1947 & 0.4999 & $0.5773 \mathrm{X}$ \\
\hline 13 & $0.6646 \mathrm{X}$ & 0.2258 & 0.4789 & -0.0361 \\
\hline 14 & 0.3273 & 0.4699 & 0.4976 & 0.2913 \\
\hline 15 & $0.7362 X$ & 0.2314 & $0.5409 \mathrm{X}$ & 0.5058 \\
\hline 16 & 0.5738 & 0.5388 & 0.1717 & $0.6731 X$ \\
\hline 17 & 0.3135 & $0.8259 X$ & $0.5349 X$ & 0.5118 \\
\hline 18 & 0.4666 & $0.6510 X$ & 0.1755 & 0.2545 \\
\hline 19 & $0.6785 X$ & 0.1164 & $0.7498 X$ & 0.1984 \\
\hline 20 & $0.5971 X$ & 0.5041 & $0.6066 X$ & 0.4961 \\
\hline 21 & 0.2932 & $0.7034 X$ & $0.5641 X$ & 0.1933 \\
\hline 22 & $0.5375 \mathrm{X}$ & 0.2318 & $0.7463 \mathrm{X}$ & 0.2187 \\
\hline 23 & -0.2831 & 0.4095 & $0.6236 \mathrm{X}$ & 0.4487 \\
\hline 24 & 0.3016 & 0.1680 & 0.3167 & $0.7373 X$ \\
\hline 25 & $0.8166 \mathrm{X}$ & 0.1117 & $0.6384 X$ & 0.4832 \\
\hline 26 & $0.7144 \mathrm{X}$ & -0.2896 & $0.5587 \mathrm{X}$ & 0.1078 \\
\hline 27 & 0.4068 & 0.4961 & 0.0793 & 0.4975 \\
\hline 28 & 0.2342 & $0.6546 X$ & 0.5048 & 0.2828 \\
\hline 29 & $0.6883 X$ & 0.1398 & 0.3781 & $0.5982 X$ \\
\hline 30 & 0.4096 & $0.5585 X$ & 0.3197 & $0.6249 X$ \\
\hline 31 & -0.0246 & 0.5081 & $0.7619 X$ & 0.4604 \\
\hline 32 & $0.6152 \mathrm{X}$ & 0.4565 & $0.5511 \mathrm{X}$ & -0.1542 \\
\hline
\end{tabular}




\begin{tabular}{llllll}
\hline & \multicolumn{2}{l}{ Policy officials } & & \multicolumn{2}{l}{ Collectives } \\
\cline { 5 - 6 } & Facilitators & Networking Servants & & Independents & Entrepreneurs \\
\hline 33 & 0.0204 & $0.5261 \mathrm{X}$ & $0.5311 \mathrm{X}$ & 0.5060 \\
34 & $0.6814 \mathrm{X}$ & 0.1745 & $0.5136 \mathrm{X}$ & 0.2811 \\
35 & $0.6656 \mathrm{X}$ & 0.4720 & $0.6924 \mathrm{X}$ & 0.2492 \\
36 & $0.6822 \mathrm{X}$ & 0.2499 & 0.5000 & 0.3162 \\
37 & $0.5649 \mathrm{X}$ & 0.0158 & 0.3289 & 0.3131 \\
38 & $0.8853 \mathrm{X}$ & 0.1933 & 0.0431 & 0.5235 \\
39 & 0.0117 & $0.5463 \mathrm{X}$ & 0.2649 & 0.0277 \\
40 & 0.5066 & 0.4459 & $0.7421 \mathrm{X}$ & 0.2842 \\
Explained variance $\%$ & 32 & 18 & 23 & 23 \\
Eigenvalue & 16.15 & 3.63 & 15.70 & 2.91 \\
\hline
\end{tabular}

$\mathrm{X}$ indicates results flagged for varimax rotation

\section{Appendix 3: Factor arrays for $Q$ sample of statements}

\begin{tabular}{|c|c|c|c|c|}
\hline \multirow[t]{3}{*}{ Statement } & \multicolumn{4}{|l|}{ Factor score } \\
\hline & \multicolumn{2}{|c|}{ Policy officials } & \multicolumn{2}{|l|}{ Collectives } \\
\hline & Facilitators & $\begin{array}{l}\text { Networking } \\
\text { Servants }\end{array}$ & Independents & Entrepreneurs \\
\hline \multicolumn{5}{|l|}{$\begin{array}{l}\text { In the collaboration process between policy } \\
\text { officials and collectives, it is important to } \ldots\end{array}$} \\
\hline $\begin{array}{l}1 \ldots \text { secure public values such as equality, } \\
\text { democracy and transparency }(\mathrm{P} 1)\end{array}$ & 0 & 3 & 1 & 2 \\
\hline $\begin{array}{l}2 \ldots \text { reward collectives when they contribute } \\
\text { to achieving policy objectives }(\mathrm{P} 2)\end{array}$ & 0 & -1 & 0 & 3 \\
\hline $\begin{array}{l}3 \ldots \text { arrange consultations between policy } \\
\text { officials, collectives and other relevant stake- } \\
\text { holders (P3) }\end{array}$ & 1 & 2 & 0 & 1 \\
\hline $\begin{array}{l}4 \ldots \text { remain at a distance to let collectives } \\
\text { make their own decisions }(\mathrm{P} 4)\end{array}$ & 1 & -1 & 1 & 0 \\
\hline $\begin{array}{l}5 \ldots \text { let politicians play a key role in defining } \\
\text { the direction }(\mathrm{P} 1)\end{array}$ & -2 & -2 & -3 & -2 \\
\hline $\begin{array}{l}6 \ldots \text { determine clear performance criteria to } \\
\text { hold collectives accountable }(\mathrm{P} 2)\end{array}$ & -2 & -2 & -2 & -1 \\
\hline $\begin{array}{l}7 \text {... let politicians and policy officials } \\
\text { determine, together with collectives and } \\
\text { their potential partner organizations, how to } \\
\text { support collectives (P3) }\end{array}$ & 0 & 1 & 0 & 1 \\
\hline $\begin{array}{l}8 \ldots \text { let collectives define their preferred } \\
\text { direction themselves and learn from one } \\
\text { another (possibly supported by policy } \\
\text { officials) (P4) }\end{array}$ & 3 & 1 & 2 & 2 \\
\hline $\begin{array}{l}9 \text {... acknowledge that impartiality and the } \\
\text { public interest come first (P1) }\end{array}$ & 1 & 1 & 0 & 1 \\
\hline
\end{tabular}




\begin{tabular}{|c|c|c|c|c|}
\hline \multirow[t]{3}{*}{ Statement } & \multicolumn{4}{|l|}{ Factor score } \\
\hline & \multicolumn{2}{|c|}{ Policy officials } & \multicolumn{2}{|l|}{ Collectives } \\
\hline & Facilitators & $\begin{array}{l}\text { Networking } \\
\text { Servants }\end{array}$ & Independents & Entrepreneurs \\
\hline $\begin{array}{l}10 \ldots \text { characterize the collaboration process } \\
\text { by a business-like relationship (P2) }\end{array}$ & -1 & -1 & -2 & -1 \\
\hline $\begin{array}{l}11 \ldots \text { compose a set of mutually agreed rules } \\
\text { of behaviour, so that parties know where } \\
\text { they stand (P3) }\end{array}$ & 0 & 0 & 0 & -1 \\
\hline $\begin{array}{l}12 \ldots \text { let collectives determine the rules of } \\
\text { play, and policy officials help where needed } \\
\text { (P4) }\end{array}$ & 2 & 0 & 2 & 0 \\
\hline \multicolumn{5}{|l|}{ Policy officials should predominantly ... } \\
\hline $\begin{array}{l}13 \ldots \text { prevent the emergence of collectives } \\
\text { from leading to undesirable situations (such } \\
\text { as exclusion, arbitrariness, etc.) (P1) }\end{array}$ & -1 & 2 & 0 & 0 \\
\hline $\begin{array}{l}14 \ldots \text { gain insight into the final performance } \\
\text { and impact of collectives (P2) }\end{array}$ & -1 & -1 & -1 & 1 \\
\hline $\begin{array}{l}15 \ldots \text {... connect relevant parties to one another } \\
\text { and facilitate the collaboration process } \\
\text { where needed (P3) }\end{array}$ & 2 & 2 & 2 & 0 \\
\hline $\begin{array}{l}16 \ldots \text { not hinder or take over collectives, they } \\
\text { are self-steering }(\mathrm{P} 4)\end{array}$ & 2 & 0 & 1 & 1 \\
\hline $\begin{array}{l}17 \text {... keep a good view and control on what } \\
\text { happens within collectives (P1) }\end{array}$ & -3 & -3 & -1 & -3 \\
\hline $\begin{array}{l}18 \ldots \text {... encourage collectives to be transparent } \\
\text { about their performance (P2) }\end{array}$ & -1 & 0 & -1 & 0 \\
\hline $\begin{array}{l}19 \ldots \text { encourage collectives to open up to col- } \\
\text { laboration possibilities (P3) }\end{array}$ & 0 & 1 & 1 & -1 \\
\hline $\begin{array}{l}20 \ldots \text { remove obstacles and barriers that } \\
\text { hinder collectives }(\mathrm{P} 4)\end{array}$ & 1 & 0 & 1 & 2 \\
\hline $\begin{array}{l}21 \ldots \text { check that nothing is done that conflicts } \\
\text { with municipal frameworks (P1) }\end{array}$ & -1 & -2 & -1 & -2 \\
\hline $\begin{array}{l}22 \ldots \text { stimulate collectives by formulating } \\
\text { smart performance agreements (P2) }\end{array}$ & -2 & -1 & -2 & -2 \\
\hline $\begin{array}{l}23 \ldots \text { work together with collectives and their } \\
\text { partners to realize public goals (P3) }\end{array}$ & 0 & 1 & -1 & -1 \\
\hline $\begin{array}{l}24 \ldots \text { take care that collectives are given the } \\
\text { freedom to develop in the direction they } \\
\text { desire }(\mathrm{P} 4)\end{array}$ & 1 & 0 & 3 & 0 \\
\hline
\end{tabular}

\section{References}

Agranoff, R., \& McGuire, M. (2001). Big questions in public network management research. JPART, 11, 295-326.

Bartels, K. P. R. (2013). Public encounters: The history and future of face-to-face contact between public professionals and citizens. Public Administration, 91(2), 469-483.

Bekkers, V., Edelenbos, J., Nederhand, J., Steijn, B., Tummers, L., \& Voorberg, W. (2014). The social innovation perspective in the public sector: Co-creation, self-organization and meta-governance. In J. 
Edelenbos, V. Bekkers, \& B. Steijn (Eds.), Innovation in the public sector: Linking capacity and leadership. London: Palgrave McMillan.

Bourgon, J. (2011). A new synthesis of public administration: Serving in the twenty-first century., Queen's Policy Studies Montreal: McGill-Queen's University Press.

Bressers, H. T. A., \& O'Toole, L. J. (2005). Instrument selection and implementation in a networked context. In P. Eliadis, M. Hill, \& M. Howlett (Eds.), Designing government: From instruments to governance. Montreal: McGill-Queen's University Press.

Brown, S. R. (1980). Political subjectivity: Applications of $Q$ methodology in political science. New Haven, CT: Yale University Press.

Considine, M. (2001). Enterprising states: The pubic management of welfare-to-work. Cambridge: Cambridge University Press.

De Moor, T. (2015). The Dilemma of the commoners. Understanding the use of common-pool resources in long-term perspective. New York: Cambridge University Press.

Denters, S. A. H. (2016). Community self-organization: Potentials and pitfalls. In J. Edelenbos \& I. van Meerkerk (Eds.), Critical reflections on interactive governance. Self-organization and participation in public governance (pp. 337-351). Cheltenham: Edward Elgar.

Dror, Y. (1968). Policy making re-examined. San Francisco: Chandler.

Dryzek, J. S., \& Berejikian, J. (1993). Reconstructive democratic theory. American Political Science Review, 87, 48-60.

Durning, D., \& Osuna, W. (1994). Policy analysts' roles and value orientations: An empirical investigation using Q methodology. Journal of Policy Analysis and Management, 13, 629-657.

Durose, C., van Hulst, M., Jeffares, S., Escobar, O., Agger, A., \& de Graaf, L. (2015). Five ways to make a difference: Perceptions of practitioners working in urban neighborhoods. Public Administration Review, 76(4), 576-586.

Edelenbos, J., Klok, P. J., \& van Tatenhove, J. (2009). The institutional embedding of interactive policy making. Insights from a comparative research based on eight interactive projects in the Netherlands. American Review of Public Administration, 39, 125-148.

Edelenbos, J., \& Van Meerkerk, I. (Eds.). (2016). Critical reflections on interactive governance. In Selforganization and participation in public governance. Cheltenham, UK: Edward Elgar.

Edelenbos, J., van Meerkerk, I. F., \& Schenk, T. (2018). The evolution of community self-organization in interaction with government institutions: Cross-case insights from three countries. American Review of Public Administration, 48(1), 52-66.

Eliadis, P., Hill, M., \& Howlett, M. (2005). Designing government: From instruments to governance. Montreal: McGill-Queen's University Press.

Eriksson, K. (2012). Self-service society: Participative politics and new forms of governance. Public Administration, 90(3), 685-698.

Gofen, A. (2015). Citizens' entrepreneurial role in public service provision. Public Management Review, $17(3), 404-424$.

Hajer, M. (2003). Policy without polity? Policy analysis and the institutional void. Policy Sciences, 36, $175-195$.

Healey, P. (2015). Citizen-generated local development initiative: Recent English experience. International Journal of Urban Sciences, 19(2), 109-118.

Hood, C. (1991). A public management for all seasons. Public Administration, 69(1), 3-19.

Howlett, M. (2000). Managing the hollow state: Procedural policy instruments and modern governance. Canadian Public Administration, 43(4), L 412-31.

Howlett, M. (2009). Governance modes, policy regimes and operational plans: A multi-level nested model of policy instrument choice and policy design. Policy Sciences, 42, 73-89.

Howlett, M. (2014). From the old to the new policy design: Design thinking beyond markets and collaborative governance. Policy Sciences, 47(3), 187-207.

Howlett, M. (2018). Selecting substantive and procedural tools in public policymaking. In M. Howlett \& I. Mukherjee (Eds.), Routledge handbook of policy design. New York: Routledge.

Jeffares, S., \& Skelcher, C. (2011). Democratic subjectivities in network governance: A Q methodology study of English and Dutch public managers. Public Administration, 89, 1253-1273.

Kleinhans, R. (2017). False promises of co-production in neighbourhood regeneration: The case of Dutch community enterprises. Public Management Review. https://doi.org/10.1080/14719037.2017.1287941.

Klijn, E. H., \& Koppenjan, J. (2016). Governance networks in the public sector. Oxon: Routledge.

Klijn, E. H., Skelcher, C. (2007). Democracy and governance networks: compatible or not? Public Administration, 85(3), 587-608.

Klijn, E. H., Van Twist, M., Van der Steen, M., \& Jeffares, S. (2016). Public managers, media influence, and governance: Three research traditions empirically explored. Administration Society, 48(9), 1036-1058. 
Lægreid, P. (2016). Public administration theories: Instrumental and value rationality. Book review. Journal of Public Administration Research and Theory, 26(3), 588-590.

Lane, J. (2000). New public management: An introduction. London: Routledge.

Levi-Faur, D. (2012). The Oxford handbook of governace. Oxford: Oxford University Press.

McKeown, B., \& Thomas, D. (2013). Q methodology (2nd ed.). Newbury Park: Sage Publications.

Nederhand, M. J., \& Van Meerkerk, I. F. (2017). Activating citizens in Dutch care reforms: framing new co-production roles and competences for citizens and professionals. Policy Politics, 46(4), 533-550.

Nederhand, M. J., Bekkers, V., \& Voorberg, W. (2016). Self-organization and the Role of Government: How and why does self-organization evolve in the shadow of hierarchy? Public Management Review, 18(7), $1063-1084$.

Noordegraaf, M., \& Abma, T. (2003). Management by measurement? Public management practices amidst ambiguity. Public Administration, 81(4), 853-871.

Osborne, D., \& Gaebler, T. (1992). Reinventing government: How the entrepreneurial spirit is transforming the public sector. Reading: Addison-Wesley.

Ostrom, E. (2010). Beyond markets and states: Polycentric governance of complex economic systems. American Economic Review, 100(June), 641-672.

Peredo, A., \& Chrisman, J. (2006). Toward a theory of community-based enterprise. Academy of Management Review, 31(2), 309-328.

Pollitt, C., van Thiel, S., \& Homburg, V. (2007). New public management in Europe: Adaptations and alternatives. Basingstoke: Palgrave MacMillan.

Powell, W. P. (1990). Neither market nor hierarchies: Network forms of organization. Research in Organizational Behaviour., 12, 295-336.

Rhodes, R. A. W. (1997). Understanding governance. Buckingham: Open University Press.

Salamon, L. (1981). Rethinking public management: Third party government and the changing forms of government action. Public Policy, 29(3), 255-275.

Schmolck, P. \& Atkinson, J. (2013). PQMethod (Version 2.33). http://schmolck.userweb.mwn.de/qmethod/ downpqwin.htm.

Sørensen, E., \& Torfing, J. (2007). Theories of democratic network governance. London: Palgrave Macmillan.

Stoker, G. (2006). Public value management. A new narrative for networked governance? American Review of Public Administration, 36(1), 41-57.

van der Steen, M. A., van Twist, M. J. W., \& Bressers, D. (2016). The sedimentation of public values: How a variety of governance perspectives guide the practical actions of civil servants. Public Personnel Management. https://doi.org/10.1177/0734371X16671369.

Watts, S., \& Stenner, P. (2012). Doing Q methodological research: Theory, method, and interpretation. London, England: Sage.

Weber, M. (1978). Economy and society. An outline of interpretive sociology. Berkley, CA: U. California Press.

Wilson, J. Q. (1989). Bureaucracy: What government agencies do and why they do it. New York: Basic Books. 